\title{
15-19 METŲ AMŽIAUS PAAUGLIŲ GYVENSENA IR SVEIKATA: DIENOS REŽIMO YPATUMAI
}

\author{
Neringa Strazdiene் ${ }^{1}$, Birutė Strukčinskien $\dot{e}^{1}$, Sigutė Norkien $\dot{e}^{2,1}$ \\ ${ }^{1}$ Klaipédos universitetas, ${ }^{2}$ Klaipédos jürininku ligoninè
}

Raktažodžiai: paaugliai, vaikai, gyvensena, sveikata, dienos režimas.

\begin{abstract}
Santrauka
Vaikų ir paauglių dienos režimas yra svarbus sveikatos veiksnys intensyvaus brendimo ir mokymosi mokykloje laikotarpiu. Gebèjimas teisingai pasirinkti veiklos ir poilsio kaitos būdus sąlygoja vaikų ir paauglių protinį darbingumą ir sveikatą. Paaugliai dažnai vis dar nesugeba tinkamai apskaičiuoti savo jẻgų, galimybių ir laiko, o tai susiję su neịsisąmoninta dienotvarkès svarba.

Tyrimo tikslas buvo analizuoti 15-19 metų amžiaus paauglių gyvenseną ir sveikatą, pagrindinị dèmesị skiriant dienos režimo ypatumams. Tyrimo metu atlikta apklausa raštu. Tirti Vakarų Lietuvos regiono devynių bendrojo ugdymo mokyklų 410 mokinių. Tiriamujų amžius - 15-19 metų.

Tyrimo rezultatai parodè, kad kasdien tinkamo dienos režimo laikosi kas dešimtas 15-19 metų amžiaus paauglys. Dienotvarkès laikymasis berniuku ir mergaičių grupèse statistiškai nesiskiria. Kasdien pusryčiauja apie pusė paauglių. Dauguma paauglių ruošia pamokas nepailsėję. Mažiau negu pusè berniukų ir apie pusè mergaičių namų darbus ruošia ne ką tik grižę iš mokyklos, bet pavalgę pietus ir pailsejję po pamokų mokykloje. Mergaitès laikosi tinkamesnio dienos režimo, negu berniukai. Mažiau negu penktadalis mergaičių ir penktadalis berniukų darbo dienomis miegojo bent 8 val. per parą. Mokslininkų siūlomų miego rekomendacijų (9-10 val. miego per parą) laikèsi tik dešimtadalis 15-19 metų amžiaus berniukų ir dar mažiau mergaičių. Savaitgaliais 9 ir daugiau valandu per parą miegojo arti pusès tirtų mergaičių ir berniukų. Tyrimas parodè, kad paaugliai per mažai ilsisi, eina per vèlai miegoti ir per mažai miega darbo dienomis. Ne visi paaugliai pusryčiauja ir daugumos jų dienos režimas yra netinkamas.
\end{abstract}

\section{Ivadas}

Žmogaus gyvenimo būdas formuojasi vaikysteje ir paauglystèje, o ịpročiai dažniausiai išlieka visam gyvenimui. Sveikos gyvensenos igūdžių formavimo (-si) svarba ypač pabréžtina paauglystēje, kai žmogaus organizmas sparčiai auga bei vystosi, ir ji gali pažeisti nepalankūs išoriniai veiksniai [1]. Nūdienos vaikų ir paauglių sveikatos sutrikimai ir negalavimai sietini su per dideliu mokymosi krūviu, netinkamu dienos režimu ir sveikos gyvensenos ipročių stoka [2]. Pasak mokslininku [2-5], dienotvarkè neatsiejama vaiko sveikos gyvensenos dalis. Kad vaikai ir paaugliai ịsisavintų gaunamą informaciją, paruoštų pamokas, padètų buityje, užsiimtų mégstama veikla, jiems reikia gerai pailsèti, teisingai pasirinkti veiklos ir poilsio kaitos būdus. Pastebèta, jog vaikai dažnai vis dar nesugeba tinkamai apskaičiuoti savo jègų, galimybių ir laiko, o tai susiję su neįsisąmoninta dienotvarkès svarba [3]. Mokslininkų [2, 6-9] teigimu, vaikysteje ir paauglysteje sveikata labiausiai priklauso nuo šeimos funkcionavimo, kuris susijęs su jos narių įsitikinimais, vertybėmis, patirtimi, kasdiene veikla. Taigi svarbu didinti tėvų ir kitų suaugusiụjų atsakomybę už vaikų ir paauglių sveikatą ir fizinę brandą, mokyti juos ir formuoti poreikị sveikai gyventi $[3,10]$.

Tyrimo tikslas - analizuoti 15-19 metų amžiaus paauglių gyvenseną ir sveikatą, pagrindinị dèmesị skiriant dienos režimo ypatumams.

\section{Tyrimo medžiaga ir metodai}

Tyrimui pasirinktas apklausos raštu metodas. Tyrimas vyko 2016 metais devyniose Vakarų Lietuvos regiono bendrojo ugdymo mokyklose: 4 miesto ir 5 rajono. Tyrime dalyvavo 410 paauglių, kuriems buvo 15-19 metų. Iš jų 192 (48,5 proc.) buvo berniukai ir 218 (51,5 proc.)- mergaitès. Duomenys apdoroti kompiuterine statistikos programa SPSS (21 versija). Statistinei duomenų analizei taikyta aprašomoji statistika, naudotas neparametrinis $\chi^{2}$ kriterijus, $t$ Student'o kriterijus. Duomenys statistiškai reikšmingi, kai $\mathrm{p} \leq 0,05$. 


\section{Tyrimo rezultatai ir jụ aptarimas}

Tyrimu siekėme sužinoti, ar dažnai 15-19 metų paaugliai laikosi dienotvarkès. Kasdien dienotvarkès laikèsi 9,4 proc. berniuku ir 13,3 proc. mergaičių, dažnai - 29,7 proc. berniuku ir 28,9 proc. mergaičiu, kartais $-42,7$ proc. berniuku ir 45,0 proc. mergaičiu, niekada $-18,2$ proc. berniukų ir 12,8 proc. mergaičių (1 pav.). Taikant $\chi^{2}$ kriterijų nustatyta, kad dienotvarkès laikymasis berniukų ir mergaičiu grupèse statistiškai nesiskiria $\left(\chi^{2}=3,288, \mathrm{p}>0,05\right)$.

Vaikų buvo klausiama, ar dažnai jie valgo pusryčius. Kasdien pusryčius valgė apie pusė apklaustujų mokinių: 54,2 proc. berniukų ir 56,0 proc. mergaičių. Net puse apklaustų mokinių nesilaikè racionalios mitybos principų ir pusryčius valgė nereguliariai arba iš viso to nedaré. Dažnai

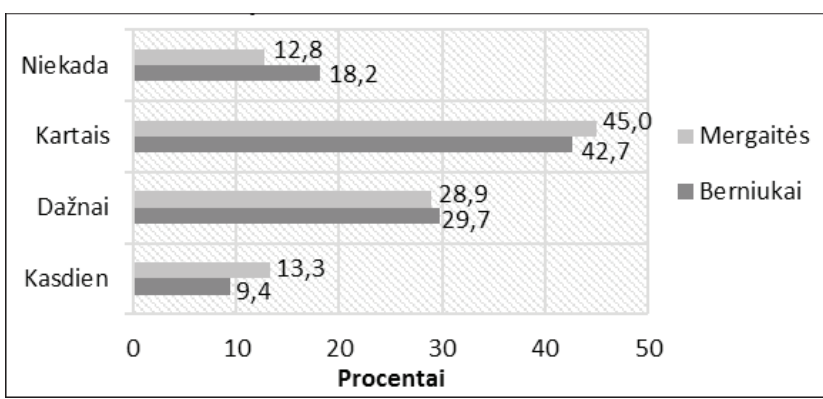

1 pav. Dienotvarkès laikymosi dažnis

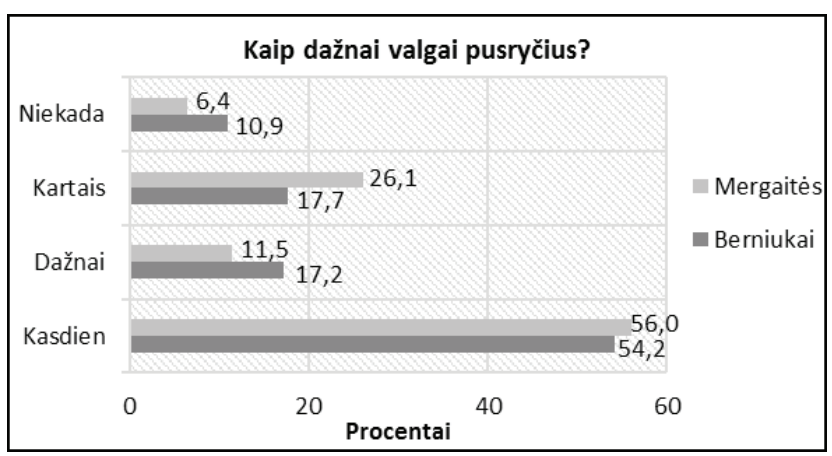

2 pav. Pusryčių valgymo dažnis

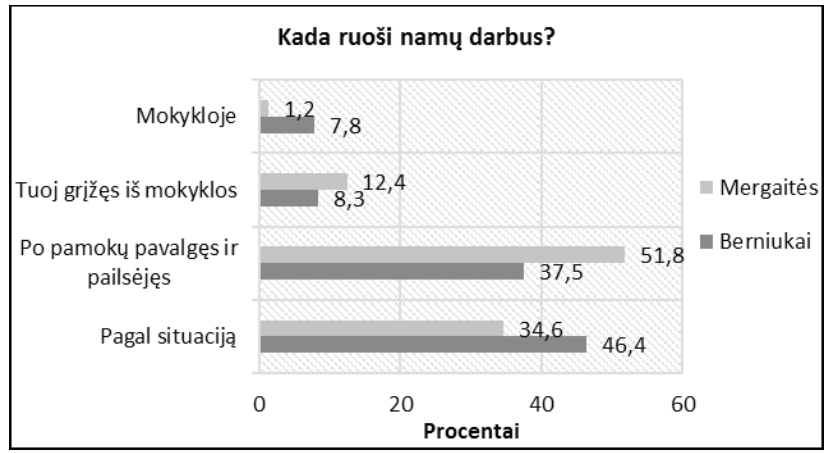

3 pav. Namų darbų ruošos aplinkybès pusryčius valgè - 17,2 proc. berniukų ir 11,5 proc. mergaičių, kartais - 17,7 proc. berniukų ir 26,1 proc. mergaičių, niekada - 10,9 proc. berniukų ir 6,4 proc. mergaičių (2 pav.). Taikant $\chi^{2}$ kriterijų nustatyta, kad pusryčių valgymas berniukų ir mergaičių grupèse statistiškai nesiskyre $\left(\chi^{2}=\right.$ $4,568, \mathrm{p}>0,05)$.

Tyrime siekėme išsiaiškinti, kada vaikai ruošia namų darbus. Sugrižž i namus iš mokyklos ir pirmiausia pavalgę pietus bei pailséję po pamokų mokykloje namų užduotis

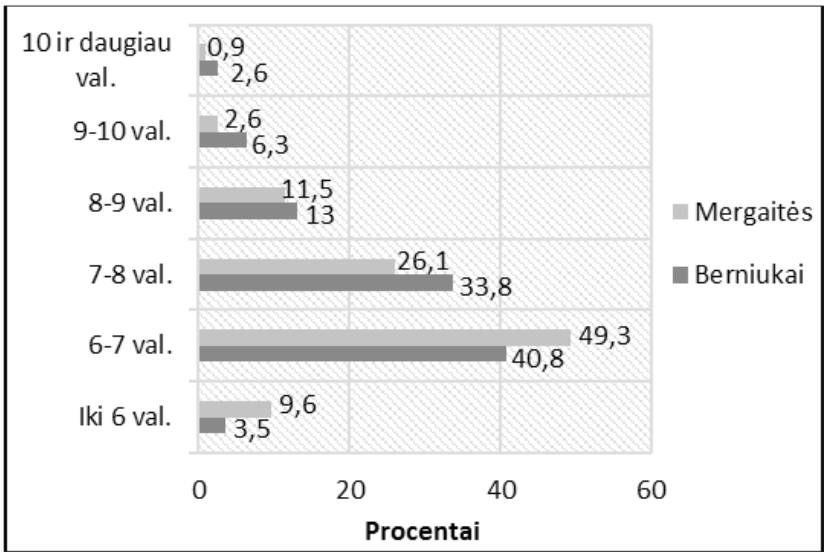

4 pav. Vaikų miego trukmè darbo dienomis

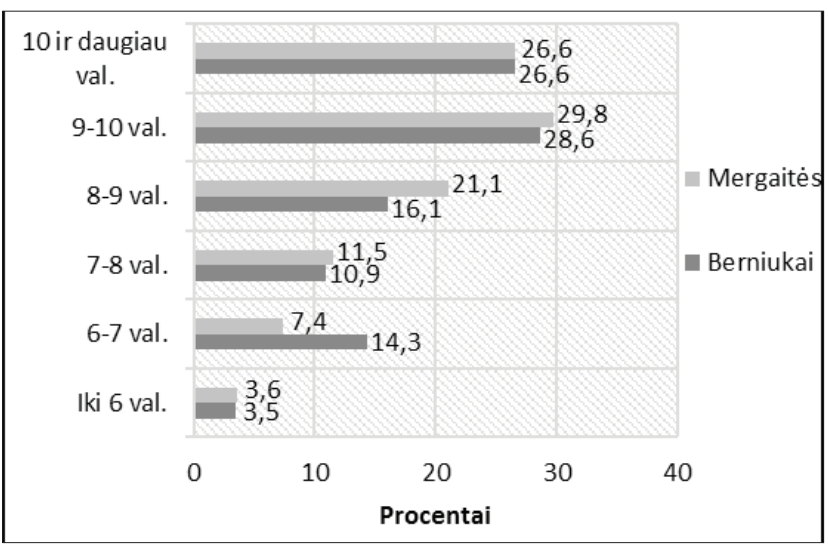

5 pav. Vaikų miego trukmè savaitgaliais

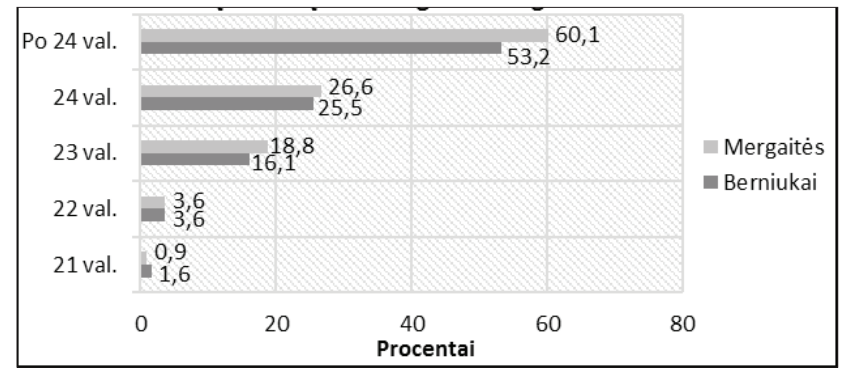

6 pav. Vaikų ejjimo miegoti laikas darbo dieną 
atliko 37,5 proc. berniukų ir 51,8 proc. mergaičiu, tuoj grižę iš mokyklos $-8,3$ proc. berniukų ir 12,4 proc. mergaičių, mokykloje $-7,8$ proc. berniukų ir 1,2 proc. mergaičių, pagal situaciją - 46,4 proc. berniukų ir 34,6 proc. mergaičių (3 pav.). Taikant $\chi^{2}$ kriterijų nustatyta, kad namų darbų ruošimas berniukų ir mergaičių grupèse skiriasi statistiškai reikšmingai $\left(\chi^{2}=17,355, p<0,01\right)$. Mergaitès dažniau namų darbus ruošè pavalgiusios ir pailsèjusios, o berniukai - pagal situaciją.

Svarbu buvo nustatyti, kokia yra vaikų miego trukmé per parą (įskaitant ir dienos miego trukmę) darbo dienomis bei savaitgaliais. Darbo dienomis iki 6 val. per parą miega 3,5 proc. berniukų ir 9,6 proc. mergaičių, 6-7 val. - 40,8 proc. berniukų ir 49,3 proc. mergaičių, 7-8 val. $-33,8$ proc. berniukų ir 26,1 proc. mergaičių, $8-9$ val. $-13,0$ proc. berniukų ir 11,5 proc. mergaičių, 9-10 val. $-6,3$ proc. berniuku ir 2,6 proc. mergaičiu ir daugiau nei 10 val. $-2,6$ proc. berniukų ir 0,9 proc. mergaičių (4 pav.). Remiantis mokslininkų rekomendacijomis, paaugliai turètų miegoti 9-10 val. per parą. Mūsų tyrimas rodo, jog šių rekomendacijų darbo dienomis laikosi tik 6,3 proc. berniukų ir 2,6 proc. mergaičių. Taikant $\chi^{2}$ kriterijų nustatyta, kad miego trukmé darbo dienomis berniukų ir mergaičių grupèse skiriasi statistiškai reikšmingai $\left(\chi^{2}=13,195, \mathrm{p}<0,01\right)$. t.y., berniukai darbo dienomis miega ilgiau negu mergaitės.

Savaitgaliais iki 6 val. per parą miega 3,3 proc. berniukų ir 3,6 proc. mergaičių, $6-7$ val. - 14,3 proc. berniukų ir 7,4 proc. mergaičių, $7-8$ val. $-10,9$ proc. berniukų ir 11,5 proc. mergaičių, $8-9$ val. - 16,1 proc. berniukų ir 21,1 proc. mergaičių, 9-10 val. - 28,6 proc. berniukų ir 29,8 proc. mergaičių ir daugiau nei 10 val. $-26,6$ proc. berniukų ir 26,6 proc. mergaičių (5 pav.). Taikant $\chi^{2}$ kriterijų nustatyta, kad miego trukmé savaitgaliais berniukų ir mergaičių grupese statistiškai nesiskiria $\left(\chi^{2}=5,281, \mathrm{p}>0,05\right)$. Tyrimas parode, jog savaitgaliais paaugliu miego trukmé ilgèja ir rekomenduojamas 9-10 valandu per parą savaitgaliais miega ženkliai daugiau paauglių negu darbo dienomis. Galima teigti, jog savaitgaliais paaugliai stengiasi kompensuoti miego darbo dienomis trūkumą. Tačiau mokslininkai pažymi, jog mie-

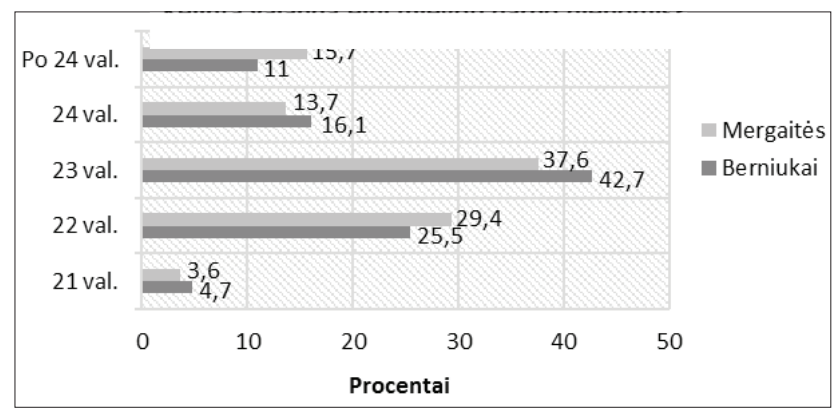

7 pav. Vaikų ejjimo miegoti laikas savaitgaliais go praradimo kompensavimas ilgesniu savaitgalio miegu, nors ir padeda, organizmui nèra sveikas ir reguliarus.

Tyrime siekème išsiaiškinti, kelintą valandą vaikai eina miegoti darbo dienomis ir savaitgaliais. Darbo dienomis 21 val. eina miegoti 4,7 proc. berniukų ir 3,6 proc. mergaičių, 22 val. - 25,5 proc. berniukų ir 29,4 proc. mergaičių, 23 val. $-42,7$ proc. berniukų ir 37,6 proc. mergaičių, 24 val. - 16,1 proc. berniukų ir 13,7 proc. mergaičių, po 24 val. - 11,0 proc. berniukų ir 15,7 proc. mergaičiu (6 pav.). Taikant $\chi^{2}$ kriterijų nustatyta, kad ejjimo miegoti laikas darbo dienomis berniukų ir mergaičių grupèse statistiškai nesiskiria $\left(\chi^{2}=2,601, p>0,05\right)$.

Savaitgaliais 21 val. eina miegoti 1,6 proc. berniukų ir 0,9 proc. mergaičiu, 22 val. $-3,6$ proc. berniukų ir tiek pat (3,6 proc.) mergaičių, 23 val. - 16,1 proc. berniukų ir 18,8 proc. mergaičiu, 24 val. $-25,5$ proc. berniukų ir 26,6 proc. mergaičiu, po 24 val. $-53,2$ proc. berniuku ir 60,1 proc. mergaičiu (7 pav.). Taikant $\chi^{2}$ kriterijų nustatyta, kad èjimo miegoti laikas savaitgaliais berniukų ir mergaičių grupése statistiškai nesiskiria $\left(\chi^{2}=3,942, \mathrm{p}>0,05\right)$.

Tyrimas parode, jog savaitgaliais paaugliai eina miegoti vèlai: 78,7 proc. berniukų ir 86,7 proc. mergaičių eina miegoti 24 val. ir vèliau. Tokiu būdu nusistovèjęs darbo dienomis miego ir poilsio režimas išbalansuojamas. Remiantis žmogaus biologiniais ritmais rekomenduojama atsigulti bent kelios valandos iki vidurnakčio, nes šios valandos atstoja kelias valandas miego vèlesniu paros metu. Nors žmogaus biologinis ritmas gali būti individualus, tačiau mokslinėje literatūroje pažymima, jog miegoti reikia tamsoje (nakties miego negali kompensuoti dienos miegas), kadangi tamsoje išsiskiria medžiagos, kurios reguliuoja ir pertvarko žmogaus organizmą.

V. Juškelienè ir kt. (2006), atlikę 11-12 klasių mokinių sveikatos ir jos pokyčių per penkerius metus studiją, nustatè, kad šio amžiaus mokinių miego trukmès darbo dienomis vidurkis buvo 7,4 val. per parą ir tik 35,4 proc. mokinių miegojo ne mažiau kaip 8 val. per parą. Atsižvelgiant i mokslininkų rekomendacijas, paaugliai turètų miegoti 9-10 val. per parą. Mūsų tyrimas rodo, jog šių rekomendacijų darbo dienomis laikosi tik mažuma tirtų paauglių, nes daugumos paauglių miego trukmè per parą darbo dienomis yra gerokai per trumpa. Mokslininkai teigia [11], kad miego trūkumą darbo dienomis vienuoliktokai ir dvyliktokai siekia kompensuoti savaitgaliais. Jų teigimu, apie 50,0 proc. respondentų šeštadieniais miega nuo 9 iki 16 val. per parą. Mūsų tyrimo duomenys panašūs - apie pusé paauglių mergaičiu ir paauglių berniukų savaitgaliais miegojo 9 ir daugiau valandų. Manoma, kad nepakankamas miegas turi reikšmès paauglių dažniems psichosomatiniams negalavimams. Dažnų negalavimų rizika tiems, kurie darbo dienomis miega mažiau nei 8 val., du kartus yra didesnè 
nei tiems, kurių miego trukmė yra 8 val. ir ilgesnè. J. Armonienė (2007), ištyrusi Vilniaus miesto 5-11 klasių mokinių dienotvarkę, teigia, kad pakankamai miega tik kas antras mokinys, net 10,2 proc. mokinių miega tik 6,5-7 val. Miego trūkumas, be abejo, atsiliepia jų protiniam ir fiziniam darbingumui. Tik 27,3 proc. tiriamųų eina miegoti prieš 21.30 val., kaip to reikalauja higienos normos. Mūsų tyrimo duomenimis, tik 4,5 proc. $15-19$ metų amžiaus mergaičių ir 5,2 proc. to paties amžiaus berniukų darbo dienomis ejo miegoti 21-22 val. Taigi dauguma paauglių nesilaiko tinkamo dienos režimo, eina miegoti per vėlai, ir jų miego trukmé per parą yra per trumpa.

\section{Išvados}

1. Dauguma paauglių laikosi netinkamo dienos režimo. Kasdien tinkamo dienos režimo laikosi kas dešimtas 15-19 metų amžiaus paauglys. Dienotvarkès laikymasis berniukų ir mergaičių grupèse statistiškai nesiskyrè.

2. Kasdien pusryčiauja apie pusė paauglių.

3. Dauguma paauglių ruošia pamokas nepailsèję. Mažiau negu pusè berniukų ir apie pusė mergaičių namų darbus ruošia ne ką tik grị̌ę iš mokyklos, bet pavalgę pietus ir pailsėję po pamokų mokykloje. Mergaitès laikosi tinkamesnio dienos režimo, negu berniukai.

4. Darbo dienomis paaugliai miega per trumpai. Mažiau negu penktadalis mergaičių ir penktadalis berniukų darbo dienomis miegojo bent 8 val. per parą. Mokslininkų siūlomų miego rekomendacijų (9-10 val. miego per parą) laikèsi tik dešimtadalis 15-19 metų amžiaus berniukų ir dar mažiau mergaičių. Savaitgaliais 9 ir daugiau valandų per parą miegojo apie puse tirtų mergaičių ir berniukų.

5. Dauguma paauglių eina miegoti per vélai - vidurnaktị (24 val.) ir vèliau.

\section{Literatūra}

1. Povilaitienè J., Butvilas T. Vaikų sveika gyvensena užtikrinant jų socializacijos palankumą. Socialinis ugdymas: postmodernios visuomenès iššñkiai vaikų ir jaunimo socializacijai, 2014; 7: 47-52.

2. Adaškevičienė E., Strazdienė N. Vaikų sveikatą stiprinančio fizinio aktyvumo ugdymas: monografija. Klaipèda: Klaipèdos universiteto leidykla, 2013.

3. Armonienė J. Mokiniu fizinis aktyvumas ir sveikata. Pedagogika, 2007; 85: 115-120.

4. Hall D., Elliman D. Health for all children. Oxford: Oxford University Press Inc 2006. http://dx.doi.org/10.1093/med/9780198570844.001.0001

5. Power TI, Dupaul GJ, Shapiro ES. et al. Promotiong children's health: integrating school, family, and community. New York: The Guilford Prees 2003.

6. Gudžinskienè V. Sveikas darželis - sveiki vaikai. Vilnius, 2011. Prieiga per internetą: http://www.ikimokyklinis.lt/index.php/ straipsniai/specialistams/sveikas-darzelis-sveiki-vaikai/3016 [žiūrèta $2016 \mathrm{~m}$. rugpjūčio 16 d.].

7. Redding S. Parents and learning. Geneva: International Academy of Education, International Bureau of Education, 2010.

8. Simpson CG, Gray JP., Waldrep S. Healthier lifestyles for young children: Partnering with families. Dimensions of early childhood 2009; 37 (1): 14-20.

9. Jociūtė A., Krupskienè A., Sabaliauskienė D., Paulauskienè N. Sveikatos stiprinimas mokyklose. Metodinès rekomendacijos. Vilnius: Valstybinis aplinkos sveikatos centras, 2008. Prieiga per internetą: http://www.smlpc.lt/media/file/Skyriu_info/ Vaiku_sveikata/SSM/Publikacijos_leidiniai/Sveikatos_stiprinimas_mokyklos-metodines_rekomendacijos.pdf [žiūrèta 2016 m. rugpjūčio $16 \mathrm{~d}$.].

10. Šopagienė D., Strukčinskienė B., Stasiuvienė D., Dalia Jurgaitienè D., Pačiauskaitė I., Neverdauskaitė G. Ikimokyklinio amžiaus vaikų mitybos ypatumai Klaipėdos mieste. Visuomenès sveikata, 2013; 1(23): 37-41.

http://dx.doi.org/10.5200/sm-hs.2013.006

11. Juškelienė V., Ustilaitė S., Proškuvienė R., Kalibatas J., Naudžiūtė S. 11-12 klasių mokinių sveikata ir jos pokyčiai per 5 metus. ŠMM užsakomojo tyrimo ataskaita. Vilnius: LR Švietimo ir mokslo ministerija, 2006. Prieiga per internetą: http:// www.smm.lt/svietimo_bukle/docs/tyrimai/11_12_moks_sveik. pdf [žiūrèta 2016 m. rugpjūčio 20 d.].

\section{LIFESTYLE AND HEALTH IN TEENAGERS AGED 15 TO 19 YEARS: FOCUS ON DAILY ROUTINE \\ N. Strazdienė, B. Strukčinskienė, S. Norkienė}

Key words: teenagers, children, lifestyle, health, daily routine. Summary

Daily routine in children and teenagers is particularly important factor of the lifestyle for their intensive development, health, and the learning abilities at school. The daily activities and the ways of relax are of importance for mental health and for working capacity of children and young people. Teenagers often do not pay attention on limitations of time and energy, and do not take enough care on appropriate daily routine. The aim of the study was to investigate the lifestyle and health in teenagers aged 15 to 19 years with focus on daily routine. The survey was conducted in nine secondary schools of Western Lithuania, and there participated 410 teenagers aged 15 to 19 years in the study. The results revealed that one in ten teenagers keep appropriate daily routine. Daily breakfast take about half of the respondents. Less than half of the boys and about half of the girls do their homework not immediately after coming back home from school, but after some relax, and after taking some meal. The girls keep significantly more appropriate daily routine that that of boys. Less than one fifth of girls and one fifth of boys were sleeping daily at least 8 hours per day. The recommendations of scientists regarding daily sleeping hours ( 9 to 10 sleeping hours per day) keep only one tenth of boys, and very few girls. About half of the surveyed girls and boys sleep nine or more hours on weekends. The majority of teenagers go to bed at midnight or later.

Correspondence to: n.strazdiene@gmail.com

Gauta 2016-09-06 